\title{
MANAGING NATURE-BASED TOURISM IN PROTECTED KARST AREA BASED ON TOURISM CARRYING CAPACITY ANALYSIS
}

\author{
INDRA A.S.L.P. PUTRI ${ }^{1 *}$, FAJRI ANSARI ${ }^{2}$, \\ ${ }^{l}$ Environment and Forestry Research and Development Institute of Makassar. Makassar, \\ South Sulawesi Indonesia. Orchid ID http://orcid.org/0000-0001-9763-8251. \\ ${ }^{2}$ Environment and Forestry Research and Development Institute of Makassar. Makassar, \\ South Sulawesi, Indonesia. Orchid ID http://orcid.org/0000-0002-1064-9757 \\ *Corresponding authore-mail: indra.arsulipp@gmail.com
}

Received: $7^{\text {th }}$ July 2020 , Accepted: $12^{\text {th }}$ July 2021

\begin{abstract}
Nature-based tourism relies on the beauty of nature to maintain sustainability and attraction. However, karst environment is vulnerable to disturbance due to tourism activity. This study, therefore, aims to analyze the social, ecological, physical, real, and effective carrying capacity of Pattunuang Assue Nature Tourism Object, Bantimurung Bulusaraung National Park. Data were collected through field measurement, observation, and interviews. Data of visitors' favorite spot and its size were measured through observation and field measurement. Visitors' perceptions related to the destination, including their duration activities were collected through interviews. It was further collected by observing the various spots of activity, and measuring the area of restrictive factors such as physical (number of rainy days), biotic (vegetation diversity at tree level, the diversity of birds during the busy visiting hours, the initial period of the Tarsius fuscus' birth). We also observe the equipment and infrastructure of the destination and collected data related to management through interviews with the managers. This study reveals various carrying capacity value which can be used as an option for the managers to choose the best way to manage destination in the right way. The result showed that particular activities exceeded carrying capacity but other activities far below their carrying capacity value. The study furthermore discusses how to deal with numerous activities. It also suggests an increase in the number of visitors by considering their ecological characteristics and management capacity.
\end{abstract}

Keywords: Karst, Tourism, Carrying Capacity, Nature-based, Protected area, Bantimurung Bulusaraung National Park

\section{INTRODUCTION}

The Indonesian government pays adequate attention to the tourism sector, owing to the belief that it will earn larger income from foreign tourists compared to oil and gas, coal, as well as palm oil. As a result of this, it targets attracting 1.5 and 20 million foreign as well as domestic tourists respectively in 2019 (DPJLHK, 2015). The Indonesian government achieves this objective by developing strategies aimed at enhancing tourist areas, such as the conservation or protected areas which have received less attention over the past years (Yahya, 2017). One of the destinations that are being intensively developed and promoted by 
the Indonesian government to support increased tourism in conservation areas is Pattunuang assue Nature Tourism Object (Pattunuang NTO). Pattunuang NTO is a karst tourism area, a part of one of the world's famous karst landscapes, namely the Maros-Pangkep karst landscape, Bantimurung Bulusaraung National Park.

Watson et al. (1997) stated that karst is sensitive to disturbances from human activity. However, tourism in karst relies on the attractiveness and uniqueness of natural beauty, flora, and fauna. Therefore, tourism in karst areas should be carried out carefully, maintaining environmental conditions and minimizing negative impacts due to tourism activities in the karst area by managing tourism based on the carrying capacity of the environment. This is in line with the opinion of Marsiglio (2015), Vujko et al. (2017), and Coccossis \& Mexa (2017) which stated that the preservation of biodiversity, beauty, and natural environmental conditions of a tourist area depend on carrying capacity of the area.

The concept of carrying capacity was initially used in biology (Chapman \& Byron, 2018), fishery, wildlife, and range management (Manning et al., 2017). Various fields that utilize natural resources applied as this concept, such as wildlife (Hagy \& Kaminski, 2015; Thapa \& Kelly, 2017), insect (Al-Ghamdi et al., 2016), microorganism (Sarker \& Wiltshire, 2017), ecosystem (Chapman \& Byron, 2018), forest (Martire et al., 2015), marine (Han et al., 2018), aquaculture (David et al., 2015), water (Ren et al., 2016), atmosphere (Zhou \& Zhou, 2017), fossil energy resources (Clancy et al., 2018). The carrying capacity concept also has been applied by the Indonesian government, which is regulated by Law No.32 of 2009 about protection and environmental management.

In tourism, the carrying capacity is essential while setting the destination's development and management plan (Coccossis, 2017; Manning e. al., 2017; Papayannis, 2017). Despite the fact that there are lots of criticism regarding the carrying capacity of tourism (Butler, 2017), sustainable management should be mandated and applied (Bera et al., 2015) in the conservation areas (Papayannis, 2017). Managing visitor as a basis idea of tourism carrying capacity is in line with tourism management in protected or conservation areas which is mainly focused on the sustainability of the destination.

The World Tourism Organization (UNWTO) defines the tourism carrying capacity as the maximum number of tourists capable of visiting a destination, without causing damages to the physical, economic, and socio-cultural quality, of the area (Coccossis, 2017; Coccossis \& Mexa, 2017; Hasan et al., 2014). Tourism carrying capacity comprises of four aspects, namely social, ecological, physical, and managerial (Hallo \& Manning, 2010). This combination of four elements determines the overall destination. The social carrying capacity is a level of a crowd or a maximum density that is tolerated or considered comfortable by tourists, within a certain period, before their destination became too crowded and they decided to relocate (Calanog, 2015; Mason, 2015; McCool et al., 2007 ). Furthermore, Graefe (1988) mention social-psychological carrying capacity, and Inkson \& Minnaert (2018); Zelenka \& Kacetl (2014) termed it to psychology carrying capacity, with area calculated for the required space by the tourists to remain satisfied while traveling. Another term is the ecological capacity which is the number of tourists and their activities accepted by the ecosystem of the natural destination, which when exceeded, is capable of damaging its habitats, plants, and wildlife (Mason, 2015). Fandeli (2002), stated that the ecological capacity is considered a recovery, natural, or turnover factor. The physical capacity measures the limit of the area, i.e., the maximum number of tourists who can be physically accommodated in an area (Calanog, 2015; Mason, 2015). However, the carrying capacity which considers managerial factors is termed effective. According to De Sousa, Pereira, Da Costa, \& Jiménez (2014), this capacity considers the ability of managers in managing natural destinations. It is also termed managerial by McCool et al. (2007). However, there is real 
carrying capacity other than the above-listed types, but its value used physical capacity which is determined by considering various correction factors. According to De Sousa et al. (2014), the real carrying capacity is the maximum number of tourists allowed in a destination object, which is reviewed based on correction factors according to the characteristics of the object.

Massiani (2012) and Salerno et al. (2013) stated that carrying capacity should be comprehensively, or multi-dimensionally reviewed, with various elements that study holistically thoroughly covered with a few combining different types of carrying capacity. Therefore, in this study, the carrying capacity of Pattunuang NTO was analyzed from multiple aspects, including social, ecological, physical, real, and effective. Through this comprehensive study, it is expected that tourism management is implemented more precisely and to secure the sustainability of Pattunuang NTO.

\section{MATERIAL AND METHODS}

\section{Study Site and Materials}

This research was conducted in 2015 at the Pattunuang NTO (Figure 1), which is one of the tourism destinations at the utilization zones of Bantimurung Bulusaraung National Park (Babul NP), it is located in Maros-Pangkep Karst Area. Administratively, Pattunuang NTO is located in Samangki Village, Simbang District, Maros Regency, South Sulawesi Province, Indonesia. Pattunuang NTO has a large area, which is 102.71 hectares and it relies on its appeal to the richness and natural beauty of karst, such as secondary forest, river, cliff with almost vertical slope, caves, and its biodiversity.

Pattunuang NTO is used for adventure tourism, such as camping, hiking, cave exploration, rock climbing, swimming, river tubing, and observing animals, such as insects (especially butterflies), reptiles, birds, as well as observation of primates, such as Tarsius fuscus, which is an endemic primate that can only be found in a limited area and it characterizes this destination.

Visitors did not use all areas of Pattunuang NTO in their activities. The favorite area is the riverbank located about 1.5 - 2.5 kilometers from the edge of the highway. The local people named the area Bisseang labboro, Jonjongan, and Mata air. The riverbank width varying from only one meter to tens of meters, which is covered by secondary forest vegetation. This area is used for camping, picnicking, hiking, trekking, and animal watching. Some spots of the Pattunuang river are used for swimming during the dry season and used for river tubing during the rainy season. Visitors who camp on the banks of the river also use river water for drinking, cooking, and toilets. Besides, there are tower karst cliffs which are used by visitors to observe animals and in some places are occasionally used as rock climbing sports. There also caves that are rarely used by visitors for cave exploration. 
Fig. 1: Map of the study site

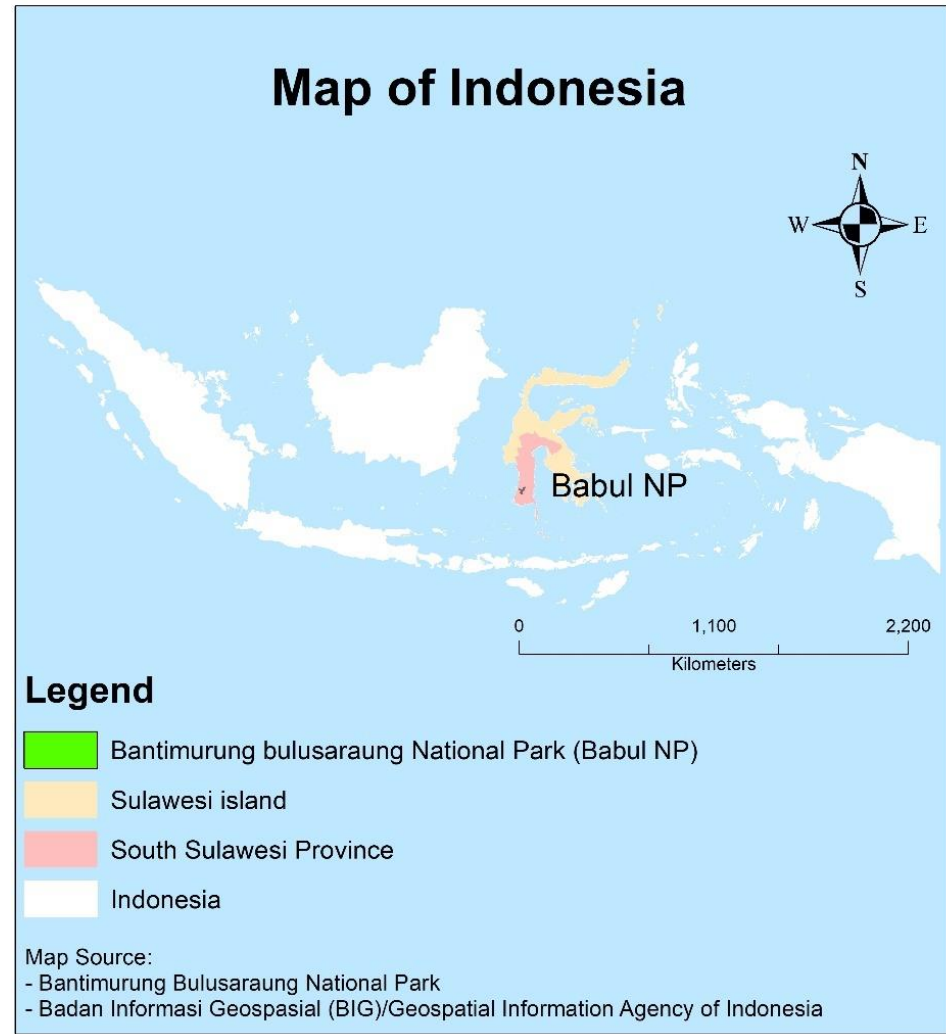

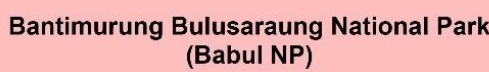

(Babul NP)

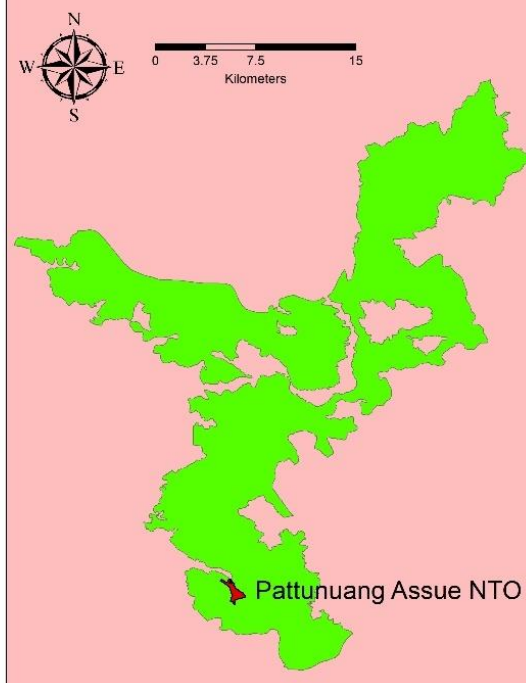

\section{Legend}

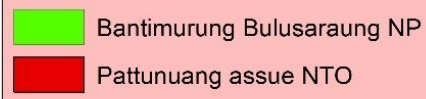

Map Source:

Bantimurung Bulusaraung National Park

\section{Methods}

Primary and secondary data were collected to calculate the value of social, ecological, physical, real, and effective carrying capacity. Primary data were collected through observation, field measurement, and interviews with Pattunuang's visitors.

The following primary data were collected in this research:

1. Data of large area used by the visitors, namely:

(A) Their access area, such as the area in front of the building of ticket booth, and the railroad which served as a route was calculated by measuring the length and width of the area in front of ticket booth and the railroad.

(B) Camping area and space where visitors relaxed to enjoy the natural scenery, along the Pattunuang riverbank (at Bisseang labboro, Jonjongan, and Mata air) were measured directly. Camping area and space are clearly distinguished from the secondary forest because this area performs the impact of visitor activity, in the form of open space without vegetation, and a short-sized plant that is resistant to trampling.

(C) The large of the Pattunuang NTO river which visitors constantly using it for swimming was measured based on observations on the average length and width of the river used for swimming. 
Putri I. A.S.L.P., Ansari F.: Managing Nature-Based Tourism in Protected Karst Area Based on Tourism Carrying Capacity Analysis

2. Rotation factor data were collected through direct observation and interviews related to the duration of visitors' activities in the Pattunuang NTO, i.e., when visitors started carrying out certain activities until they stop and leave the destination.

3. Number of rainy days, based on the Maros Regency rainy days in 2015 (Indonesian Central Bureau of Statistics, 2017)

4. Data on the number of days used by visitors was collected through direct observation.

5. Vegetation data were collected using the line transect method.

6. Data on bird diversity when the destination is crowded by visitors was collected using the point count method (Putri et al., 2019).

7. Data sensitive period of $T$. fuscus, an endemic animal and characterizes this destination. The sensitive period is a vulnerable time for T. fuscus from disturbance that can make it get ill or die. Sensitive period data of T. fuscus (both mother and newborn) during the early childbirth period was collected by observing the time of birth or birth season within a year. The sensitive period of T. fuscus occurs from the beginning of birth until the newborn is about a week old.

8. Facilities and infrastructure data, and data on the number of officers directly managing the Pattunuang Resort and their activities were also collected.

9. Data collected through interviews, such as a large area that required by visitors to feel comfortable during the trip, a large area that can still be tolerated and provided comfort to the visitors, the area which according to visitors should require the restriction or arrangement, and the area that has been considered too crowded that caused visitors decided to leave the object or move to another destination (Hallo \& Manning, 2010). Besides, data related to the distance between visitors or groups (Hasan et al., 2014) and length of stay (Kruger \& Saayman, 2014) were collected. Interviews were conducted directly using questionnaires (Sayan \& Atik, 2011), which comprised of a combination of open and closed questions as well as a Likert scale (Zacarias et al., 2011). However, the interviewer asked in-depth questions to gather more information. The interview was conducted on Pattunuang's visitors willing to be interviewed (accidental sampling) (Etikan, 2016).

The majority of the visitors come in a group, therefore, the numbers of respondents chosen were dependent on the size of the group. One respondent was chosen for a small group (less than five people), two from a group of 5 to 20 people, and three to four from a group of more than twenty people.

To determine the minimum number of respondents, we collected the number of Pattunuang NTO's visitors in 2014. A minimum number of visitors as respondents was calculated by Slovin's formula (Tejada \& Punzalan, 2012):

$$
\mathrm{n}=\frac{N}{1+N e^{2}}
$$

where: $\mathrm{n}=$ minimum sample size

$$
\begin{aligned}
& \mathrm{N}=\text { number of visitors } \\
& \mathrm{e}=\text { margin of error } 10 \%
\end{aligned}
$$

The number of Pattunuang's visitors in 2014 was 4,139. According to the formula above, the minimum number of respondents was 97 . This study interviewed 109 respondents, which exceeded the minimum number of sample requirements. 


\section{Statistical Analysis}

Analysis data was conducted through:

1. The carrying capacity on several sites made up of visitors that conducted their activities on it, such as (A) access area to ticket booth and railroad, (B) spots along the riverbanks, especially on the 1500 to 2500 meters from the boundary, (C) Pattunuang river, is 1700 to 2500 meters from the boundary (Bisseang labboro, Jonjongan, Mata air). Its carrying capacity was comprehensively analyzed, which covered the social, ecological, physical, real, and effective carrying capacity.

2. Social carrying capacity was analyzed based on the visitors' interview. They were asked to reveal their level of density that made them feel (1) comfortable and preferred, (2) acceptable, (3) request restriction, and (4) other attributes which made them chose another destination (Hallo \& Manning, 2010).

3. Ecological carrying capacity is defined as the number of visitors or visits that an area can sustain without degrading natural resources (Sievänen, 2004). It was calculated by determining the value of the required area for a particular activity (AR) (Douglass, 1975; Fandeli, 2002):

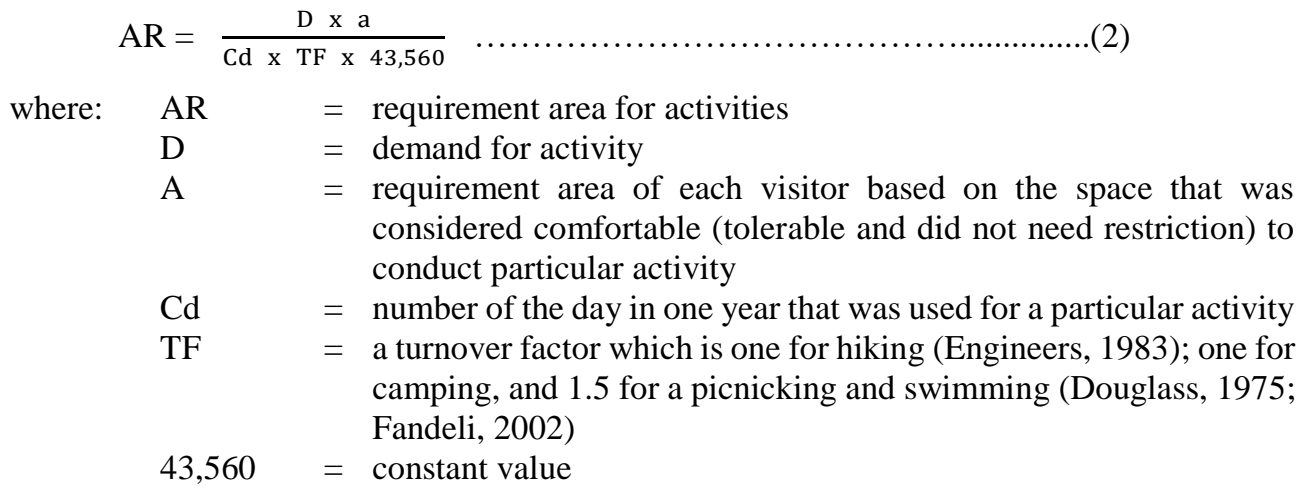

$\mathrm{AR}$ is the value of the required area for a particular activity. Furthermore, to find out the number of people who can be accommodated with a certain area without causing damage to natural resources, or in accordance with its ecological carrying capacity, the formula used:

Ecological carrying capacity: $\frac{\text { number of visitors }}{\mathrm{AR}}$ (Fandeli, 2002) (3)

4. Physical capacity is the maximum number of visitors that physically fit on a particular available space in the destination. Physical carrying capacity was analyzed based on Cifuentes' formula (Bera et al., 2015; De Sousa et al., 2014; Mashayekhan et al., 2014):

$$
\mathrm{PCC}=\mathrm{A} \times 1 / \mathrm{B} \times \mathrm{Rf}
$$

where: $\quad$ PCC $=$ physical carrying capacity

$$
\begin{array}{ll}
\mathrm{A} & =\begin{array}{l}
\text { available area for public activity } \\
\mathrm{B}
\end{array} \quad \begin{array}{l}
\text { large requirement area of the visitor which provides satisfaction } \\
\mathrm{Rf}
\end{array} \quad \begin{array}{l}
\text { rotation factor, open hours of destination compared to the } \\
\text { average time consumed by the visitor in the destination }
\end{array} \\
\mathrm{Rf}=\frac{\text { working duration }}{\text { the average time of pleasure }}
\end{array}
$$


Putri I. A.S.L.P., Ansari F.: Managing Nature-Based Tourism in Protected Karst Area Based on Tourism Carrying Capacity Analysis

5. Real carrying capacity is the maximum number of visitors that visit the destination based on the correction factor according to the destination's condition. It was calculated using the formula (De Sousa et al., 2014; Rahmani et al., 2015):

$$
\mathrm{RCC}=\mathrm{PCC}-\mathrm{Cf} 1-\mathrm{Cf} 2-\cdots . \mathrm{Cfx} \ldots \ldots \ldots \ldots \ldots \ldots \ldots \ldots \ldots \ldots \text { (6) }
$$

where: $\mathrm{Cf}=$ correction/limiting factor expressed as a percentage

$$
\mathrm{RCC}=\text { PCC } \times \frac{100-\mathrm{Cf} 1}{100} \times \frac{100-\mathrm{Cf} 2}{100} \times \frac{100-\mathrm{Cf} x}{100}
$$

$$
\text { where: } \begin{array}{ll}
\mathrm{RCC} & =\text { real carrying capacity } \\
\mathrm{PCC} & =\text { physical carrying capacity } \\
\mathrm{Cf} & =\text { correction factor }
\end{array}
$$

$$
\begin{aligned}
& \mathrm{Cfn}=\frac{\mathrm{Mn} \times 100}{\mathrm{Mt}} \\
& \text { where: } \mathrm{Cfn}^{\mathrm{Mt}}=\text { Correction factor to } \mathrm{n} \\
& \mathrm{Mn} \quad=\mathrm{A} \text { real condition at fn variable } \\
& \mathrm{Mt}=\mathrm{A} \text { maximum limit at fn variable }
\end{aligned}
$$

The correction factor is a parameter of biophysical condition on Pattunuang NTO capable of impeding visitors visitation, reduce the level of convenience and satisfaction. These parameters were obtained through preliminary interviews with 15 visitors. They stated that a restrictive factor in traveling in Pattunuang NTO such as physical parameter is a rainy day (Cf1), discourages them from traveling to Pattunuang NTO.

Other physical parameters that also act as a restrictive factor for visitors especially those that want to swim in the river is its cleanliness (Cf2). This restrictive factor used total suspended solid (TSS) and total dissolved solid (TDS) parameters, which was obtained by analyzing a water sample of Pattunuang river in the Productivity and Water Quality laboratory, Faculty of Marine and Fisheries Sciences, Hasanuddin University.

Biotic factors which are influenced by the presence of visitors is also a restrictive component. The interviews indicated that degradation of biotic factors such as natural condition and beauty (tall and green trees), as well as song's of bird, affected their satisfaction level. Therefore, the biotic factors were chosen as a correction factor were diversity value of vegetation at the tree level (Cf3) and of birds at the busy time of the visitor's visitation (weekends and holidays) (Cf4) were noted (Putri et al., 2019). Another biotic factor that was also considered a restriction for visitors was the sensitive period or early period of newborn T. fuscus (Cf4). Pattunuang NTO is a habitat of T. fuscus, a rare, endemic, and protected nocturnal primate and characterize this destination. Based on the observations, several locations of visitors' camp were located around T. fuscus nest. However, the early period of birth is a vulnerable period for its newborn and female parent. At an early age after birth, it is relatively weak, thereby, prone to a high mortality rate. Besides, postpartum T. fuscus has a high level of stress. Therefore, the presence of visitors potentially disrupts the mother and her newborn. 
The diversity index of vegetation and animals were calculated using the formula:

$$
\Sigma \mathrm{H}^{\prime}=-\sum \text { pi ln pi } \quad \text { (Fachrul, 2012). }
$$

where: $\mathrm{H}^{\prime} \quad=$ biodiversity index of vegetation and animals

6. Effective carrying capacity is the maximum number of visitors under the capacity of the manager. It was calculated based on the formula (Bera et al., 2015; De Sousa et al., 2014):

$$
\mathrm{ECC}=\mathrm{RCC} \times \mathrm{MC}
$$

where:

$\mathrm{ECC}$
$\mathrm{RCC}$
$\mathrm{MC}$

$$
\begin{array}{ll}
= & \text { effective carrying capacity } \\
= & \text { Real carrying capacity } \\
& \text { management capacity was measured by considering } \\
& \text { various modifying factors from De Sousa et al } . \\
& (2014)
\end{array}
$$

The management capacity used the formula:

$$
\mathrm{MC}=\frac{\mathrm{Rn}}{\mathrm{Rt}} \times 100 \%
$$

where: $\mathrm{MC}=$ management capacity of destination

$\mathrm{Rn} \quad=$ management capacity requirement

Rt = availability of management capacity

The factors considered in measuring the management capacity include the availability of infrastructure, number of employees, services in tourism destination encountered during the study, as shown in Table 1.

Table 1: Management capacity values indicator

\begin{tabular}{ll}
\hline \multicolumn{1}{c}{ Indicators } & Management capacity values \\
\cline { 2 - 2 } Availability and condition of the bathroom & Lower=1 Middle=2 Higher=3 \\
Availability and condition of toilets/WC & \\
Availability and condition of the trash can & \\
Availability and lighting conditions & \\
Availability and road trail conditions \\
Availability of supporting facilities for visitors' activities \\
Availability and condition of announcement boards, directions, petitions, \\
restrictions \\
Number of officers/employees \\
Routine control (daily, hourly) of the officer on tourism activity \\
Availability of safety equipment for early rescue \\
Availability of first aid facilities/medicines
\end{tabular}

The physical carrying capacity is generally higher than the real value which may be equal to or greater than the effective. In other words, the value of PCC is greater than (>) RCC and greater than or equal to $(\geq)$ ECC (Bera et al., 2015; Queiroz et al., 2014). 


\section{RESULTS}

The visitors and managers only utilize a small area of the total destination, which is seen from the concentration of visitors, at a certain point. Based on the measurement of the favorite visitors' spot, visitors used railroad approximately $4000 \mathrm{~m}^{2}$, area for picnic and camping around $2380.85 \mathrm{~m}^{2}$, and area for swimming around $2038.40 \mathrm{~m}^{2}$.

Based on interviews with Pattunuang NTO officers, carrying capacity was not been implemented optimally in managing this destination. However, visitors only use a narrow area in their activities, but on the other hand, the number of visitors increased year to year. In 2015, the number of visitors visiting Pattunuang NTO reached 7,395 people (Figure 2). Therefore, managers should start using management policies based on tourism carrying capacity.

Fig. 2: Number of visitors of Pattunuang NTO in 2011-2015

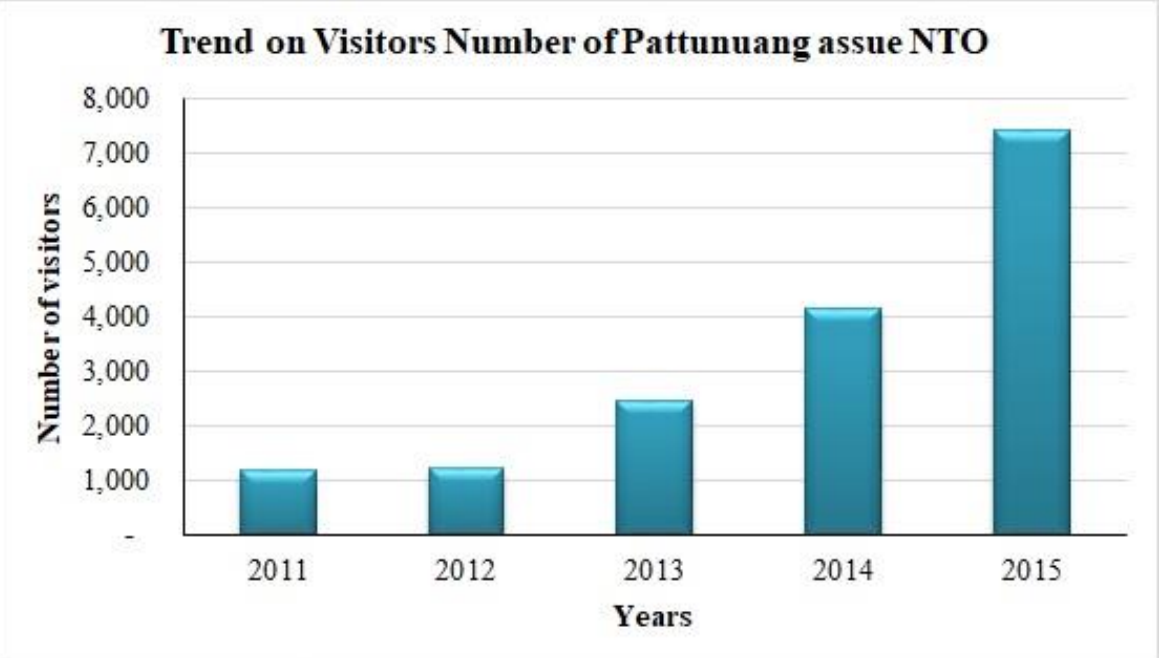

Data source: Bantimurung Bulusaraung National Park

The values of environmental carrying capacity, including social, ecological, physical, real, and effectiveness, in various areas utilized by visitors, such as railroad, riverbank, and river show at Table $2-6$. These values were obtained by the assumption that there was no change in the destination, for example, by opening a new spot in the destination.

\section{Social carrying capacity}

Based on interviews related to the level of a large area which tolerated by visitors according to their needed show at Table 2 . 
Table 2: The value of social carrying capacity at Pattunuang NTO

\begin{tabular}{|c|c|c|c|c|c|c|c|}
\hline \multirow{2}{*}{ Location } & \multirow{2}{*}{ Activities } & \multirow{2}{*}{ Analysis method } & \multicolumn{4}{|c|}{ Large area $\left(\mathrm{m}^{2} /\right.$ person $)$} & \multirow{2}{*}{$\begin{array}{c}\text { Carrying } \\
\text { capacity value } \\
\text { (person/day) }\end{array}$} \\
\hline & & & $\begin{array}{c}\text { Most } \\
\text { favorable }\end{array}$ & $\begin{array}{l}\text { Can be } \\
\text { tolerated }\end{array}$ & $\begin{array}{l}\text { Requiring } \\
\text { restriction }\end{array}$ & $\begin{array}{l}\text { Might be } \\
\text { abandoned }\end{array}$ & \\
\hline \multirow[t]{4}{*}{ railroad } & road pass & $\begin{array}{l}\text { visitor's density that most } \\
\text { favorable }\end{array}$ & 3.19 & & \multirow{4}{*}{0.99} & & 1,254 \\
\hline & & $\begin{array}{l}\text { visitors density that can } \\
\text { still be tolerated }\end{array}$ & & 1.33 & & & 2,997 \\
\hline & & $\begin{array}{l}\text { visitors density requiring } \\
\text { restrictions }\end{array}$ & & & & & 4,040 \\
\hline & & $\begin{array}{l}\text { visitors density that } \\
\text { causes them to cancel a } \\
\text { trip }\end{array}$ & & & & 0.565 & 7,079 \\
\hline \multirow[t]{8}{*}{ riverbank } & picnic & $\begin{array}{l}\text { visitor's density that most } \\
\text { favorable }\end{array}$ & 15.14 & & \multirow{4}{*}{2.48} & & 157 \\
\hline & & $\begin{array}{l}\text { visitors density that can } \\
\text { still be tolerated }\end{array}$ & & 5.99 & & & 397 \\
\hline & & $\begin{array}{l}\text { visitors density requiring } \\
\text { restrictions }\end{array}$ & & & & & 958 \\
\hline & & $\begin{array}{l}\text { visitors density that } \\
\text { causes them to cancel a } \\
\text { trip }\end{array}$ & & & & 1.056 & 2,257 \\
\hline & \multirow[t]{4}{*}{ camping } & $\begin{array}{l}\text { visitor's density that most } \\
\text { favorable }\end{array}$ & 32.77 & & \multirow{4}{*}{11.48} & & 73 \\
\hline & & $\begin{array}{l}\text { visitors density that can } \\
\text { still be tolerated }\end{array}$ & & 21.16 & & & 112 \\
\hline & & $\begin{array}{l}\text { visitors density requiring } \\
\text { restrictions }\end{array}$ & & & & & 207 \\
\hline & & $\begin{array}{l}\text { visitors density that } \\
\text { causes them to cancel a } \\
\text { trip }\end{array}$ & & & & 4.88 & 488 \\
\hline \multirow[t]{4}{*}{ river } & \multirow[t]{4}{*}{ swimming } & $\begin{array}{l}\text { visitor's density that most } \\
\text { favorable }\end{array}$ & 10.91 & & \multirow{4}{*}{2.93} & & 187 \\
\hline & & $\begin{array}{l}\text { visitors density that can } \\
\text { still be tolerated }\end{array}$ & & 5.596 & & & 364 \\
\hline & & $\begin{array}{l}\text { visitors density requiring } \\
\text { restrictions }\end{array}$ & & & & & 697 \\
\hline & & $\begin{array}{l}\text { visitors density that } \\
\text { causes them to cancel a } \\
\text { trip }\end{array}$ & & & & 1.35 & 1,513 \\
\hline
\end{tabular}

Table 2 shows that every location and visitors' activities have different social carrying capacity values. Level of visitors comfort influenced value of carrying capacity, thus the lowest value of carrying capacity was obtained from the highest level of visitors comfort.

\section{Ecological carrying capacity}

Based on interview results to the visitors regarding their activities, demand for a picnic around $48.62 \%$, camping $51.38 \%$ and swimming $36.7 \%$. The value of ecological carrying capacity of Pattunuang NTO shows in Table 3. 
Putri I. A.S.L.P., Ansari F.: Managing Nature-Based Tourism in Protected Karst Area Based on Tourism Carrying Capacity Analysis

Table 3: The ecological carrying capacity of Pattunuang NTO

\begin{tabular}{|c|c|c|c|c|c|c|c|}
\hline Location & Activities & $\begin{array}{c}\mathrm{D} \\
\text { (person) }\end{array}$ & $\mathrm{a}\left(\right.$ feet $\left.^{2}\right)$ & $\begin{array}{c}\mathrm{Cd} \\
\text { (day/year) }\end{array}$ & $\begin{array}{c}\text { AR } \\
\text { (acre) }\end{array}$ & $\begin{array}{c}\text { Ec CC } \\
\text { (person/Ha) }\end{array}$ & $\begin{array}{l}\text { Ec CC base on the } \\
\text { used Pattunuang } \\
\text { area by visitors for } \\
\text { a certain activity }\end{array}$ \\
\hline railroad & road pass & 7,395 & 14.36 & 255 & 0.01 & 737 & 295 \\
\hline \multirow[t]{2}{*}{ riverbank } & picnic & 3,595 & 64.48 & 255 & 0.02 & 245 & 58 \\
\hline & camping & 3,800 & 227.81 & 255 & 0.09 & 85 & 20 \\
\hline river & swimming & 2,714 & 60.24 & 255 & 0.01 & 260 & 53 \\
\hline
\end{tabular}

Table 3. shows that demand for a certain activity (D) and required area (AR) determined the value of carrying capacity. Furthermore, this table showed that the value of ecological carrying capacity was lower than the value of social carrying capacity.

\section{Physical carrying capacity}

Based on the large area that is available and used by visitors, the need of area and rotation factor, value of physical carrying capacity show in Table 4.

Table 4: The physical carrying capacity of Pattunuang NTO

\begin{tabular}{llcccc}
\hline \multicolumn{1}{c}{ Location } & Activity & $\mathrm{A}\left(\mathrm{m}^{2}\right)$ & $\mathrm{B}\left(\mathrm{m}^{2}\right)$ & $\mathrm{Rf}$ & $\mathrm{PCC}$ (person/day) \\
\hline railroad & road pass & 4,000 & 1.33 & 43.44 & 2,232 \\
riverbank & Picnic & $2,380.85$ & 5.99 & 2.88 & 1,145 \\
& Camping & $2,380.85$ & 21.17 & 2.09 & 235 \\
river & Swimming & $2,038.40$ & 5.6 & 4.65 & 1,695 \\
\hline
\end{tabular}

The results showed that the physical carrying capacity value of Pattunuang NTO was influenced by the rotation factor. Increasing rotation factor increased value of physical carrying capacity.

\section{Real carrying capacity}

The real carrying capacity of Pattunuang NTO shows at Table 5.

Table 5: The real carrying capacity of Pattunuang NTO

\begin{tabular}{lllcccccc}
\hline Location & Activity & $\begin{array}{c}\text { rainy } \\
\text { day }\end{array}$ & $\begin{array}{c}\text { river } \\
\text { cleanliness } \\
\text { /TDS }\end{array}$ & $\begin{array}{c}\text { river } \\
\text { cleanliness } \\
\text { /TSS }\end{array}$ & $\begin{array}{c}\text { diversity } \\
\text { and flora } \\
\text { condition }\end{array}$ & $\begin{array}{c}\text { diversity } \\
\text { of fauna }\end{array}$ & $\begin{array}{c}\text { early period of } \\
\text { T.fuscus } \text { birth }\end{array}$ & $\begin{array}{c}\text { RCC } \\
\text { (person } \\
\text { /day) }\end{array}$ \\
\hline railroad & road pass & 0.60 & & & 0.52 & 0.56 & 0.94 & 1,329 \\
riverbank & picnic & 0.60 & & & 0.52 & 0.56 & 0.94 & 188 \\
river & camping & 0.60 & & & & & & 39 \\
\hline
\end{tabular}

Table 5 shows carrying capacity values from various locations at Pattunuang NTO which calculated correction factors. These correction factors were used for limiting factors. This table also shows that the real carrying capacity value was lower than the physical carrying capacity value. 


\section{Effective carrying capacity}

The next type of carrying capacity is the effective carrying capacity, which is carried out using the management capacity factor. Based on the interview results, the value of management capacity of Pattunuang NTO is 0.36 (36.36\%), thus the value of the effective carrying capacity of its destination can be seen in Table 6 below.

Table 6: The effective carrying capacity of Pattunuang NTO

\begin{tabular}{llc}
\hline \multicolumn{1}{c}{ Location } & \multicolumn{1}{c}{ Activity } & ECC (person/day) \\
\hline railroad & road pass & 483 \\
riverbank & picnic & 69 \\
& camping & 14 \\
river & swimming & 70 \\
\hline
\end{tabular}

Table 6 shows that the destination needs good management capacity. Pattunuang NTO which had low management capacity caused the effective carrying capacity value of this destination was much lower than its real and physical carrying capacity value.

\section{DISCUSSION AND CONCLUSION}

Data analysis showed different values of the tourism carrying capacity. The values obtained were the result of considerations from various aspects of the natural destination. It is also in line with Salerno et al. (2013) who stated that the tourism carrying capacity is multidimensional and there were various ways to determine the threshold value. The various values of Pattunuang NTO carrying capacity will support each other to guide the management of the destination in the right way. The benefit of having different values of carrying capacity will help the manager to choose the best technique, which is appropriate to the purpose of the destination.

The varied value of carrying capacity is not a barrier (Massiani, 2012) but it supports and establishes management standards (Coccossis, 2017), as well as formulates policy strategies and control on management (Salerno et al., 2013). These various carrying capacity values of Pattunuang NTO allow managers to regulate visitors to prevent the number of visitors exceed carrying capacity values.

The data analysis showed the important role of the value of the visitors' requirement or tolerated area for their activity. The area needs for Pattunuang NTO visitors' activities are relatively small compared to the area needs for American tourists according to Douglass (1975) report. Consequently, the social carrying capacity value of Pattunuang NTO is higher than the value of American tourists for the same size tourism area.

Data analysis also showed that there is a significant contribution of rotation factor at the higher value of carrying capacity. For example, the railroad which has the higher rotation factor value will have the highest physical carrying capacity value. The high rotation factor at the location due to the railroad is generally used as an access to enter and leave their favorite sites. Therefore, visitors are only given limited time to utilize the area. Furthermore, the ecological impacts on these areas (e.g., railroad, the majority was used for ways only), were small and classified as less consuming natural resources.

Data analysis shows that the high carrying capacity value of the railroad significantly contributed to the total carrying capacity value because the railroad had a high rotation factor, requirement size area for each visitor was small, and limiting environment/correction factor was low. However, the railroad only acts as access to the main tourism area, thus the carrying capacity value of the railroad should be excluded in arranging the number of visitors. 
Putri I. A.S.L.P., Ansari F.: Managing Nature-Based Tourism in Protected Karst Area Based on Tourism Carrying Capacity Analysis

Management should use carrying capacity value of main tourism areas (river and riverbank spots, around $1500 \mathrm{~m}-2500 \mathrm{~m}$ from boundary) in arranging the number of visitors. The carrying capacity value of railroad will be useful to regulate visitors number when the railroad arranges to be an attractive spot, thus visitors not only use river and riverbank as the main location.

The results also show that the consideration of various environmental limiting factors in accordance with the local environmental conditions of the destination (turnover factor value, number of rainy days, level of natural degradation) affects the carrying capacity value. This value helps the manager to determine the limits on the number of visitors that can be tolerated by the environmental conditions and also allow the environment to recover. The area where visitors utilized more often, had high levels of natural resource consumption, and ecological impact from usage, such as riverbank and river areas (using for camping, picnicking, and swimming), have a smaller value of ecological carrying capacity compared to other types.

\section{Management strategies}

The average visitation rate per day is only around 32 people, which showed that the value of visitors was far below the tourism carrying capacity. However, it turns out that there was tourism activity conducted at some point of a location at certain times, which exceeded the maximum number of ecological and effective carrying capacity, for instance, camping in holidays. Although other tourism activities were still lower. Therefore, it requires a management pattern that can overcome these two contradictions.

Efforts to increase the number of tourists but at the same time overcome the excess number of visitors at certain points in Pattunuang NTO can be done by reducing the pressure of camping tours on holidays through the spread of overtime management, and by promoting camping out of favorite time/holiday. Furthermore, managers tend to increase camping capacity through the spread of space management, by directing visitors to spread and occupy the unfavorite and rarely occupied locations. Another way is the improvement of infrastructure by organizing the existing camp area to optimize space. The camping carrying capacity is also increased by expanding camping areas, for example, by opening new campsites near favorite areas without destroying the natural environment. Enlarging the area is needed because camping activity requires a larger space than other tourism activities, such as picnics and swimming. Additionally, opening a new tourism center is possible because the utilized area is smaller than the total area of Pattunuang NTO.

Furthermore, tourist areas should be enhanced by increasing its capacity through the organization space and renewing the tourist attractions based on visitor's preferences. For example, the majority of visitors preferred the beauty of the karst panorama, thus they choose a location that has more beautiful panorama as a favorite location. The management should be more creative to get benefit from this situation by creating an attraction that using the beauty of karst. They also can create new attractions that use other panoramas such as river, and forest within flora and fauna. Visitors of Pattunuang NTO also preferred the natural/original environment. Therefore, they choose a location within a distance that is not too close to the entrance and highway because it gave a more natural impression and free from pollution. However, it seems that visitors also do not like to walk too far. Therefore, they choose a location within a distance not too far from the entrance gate. In the early stages, the arrangement of the tourist area should be conducted at a range not too far from the main visitors' activity site and entrance gate, for example in the open space which is mostly located around Pattunuang riverbank (between 0 to 1500 meters from the boundary). 
The majority of visitors of Pattunuang NTO were adventurers, therefore, management can create and promote adventure activities as its destination image. For example, caving and cave tours, rock climbing and tower karst tour, river tour, and forest karst tours. The manager also needs to promote segments with smaller visitors e.g., trekking, hiking, birdwatching, or watching wildlife such as endemic fauna T. fuscus.

Another factor in increasing the number of visitors is understanding their characteristics (Moscardo, 2017). Managers need to figure out the aspects of visitors, such as age, behavior, favorite activities, and distribution in the area. Understanding their characteristics will make the manager obtain appropriate management to maintain the sustainability of natural resources in the destination. For example, most visitors of the Pattunuang NTO were young and motivated to camping. The manager can increase the number of visitors by increasing promotion to young visitors. However, considering the condition of Pattunuang NTO which is suitable for family tourism, the manager should also start targeting visitors who prefer family adventure tourism, from various segments and ages.

Young tourists who like adventurous tourism, such as camping, cause high consumption of natural resources. Manning et al. (2017) and Hammitt et al. (2015) stated that the utilization of natural resources for camping is much higher than other tourism activities. The use of natural resources arises due to the usage of wood for campfires and cooking which is a routine activity of campers. The campfire has an ecological impact (Reid \& Marion, 2005), for instance, the smoke and heat from fires, impact to the vegetation due to the use of wood as fuel, as well as the impact to litter and organic material due to the use of rotted timber and litter. Furthermore, visitors sometimes do not pay attention to the ecological impacts that arise from their activities. They set up their camp using the tree as a tent pole, and this activity may lead to a decrease in plants, especially at the level of sapling and pole. In the long term, losing tree will reduce the beauty of panorama which occurs due to the absence of vegetation. Visitors of Pattunuang NTO also seems to have low awareness to maintain cleanliness. It is reflecting on the waste that was abandoned and scattered in the destination area. However, bad behavior tends to degrade the quality of the environment and further decrease the carrying capacity of the destination. Therefore, the manager should routinely give advice to visitors regarding how to be a good traveler, and reprimand visitors who will damage the environment. Managers can also install information boards, and brochure that contain rules and procedures for travel, as well as routinely conduct patrols to monitor tourism area.

Other important factors that need attention were the low value of the capacity management, which was only $36.36 \%$. Increasing this carrying capacity strengthens the ability of a destination to compete with other tourism centers. Besides, it also increases visitors satisfaction rate and improves the ability of managers to preserve natural resources. Managers management capacity is increased through the addition and improvement of quality and ability of human resources. For example, the manager needs to improve services and friendliness of officers, routinely attend tourist sites as well as regularly control and monitor the visitors' activities and the condition's destination. Since most of the Pattunuang NTO visitors are special interest travelers, it needs to increase the number and capability of officers with expertise in handling, serving, monitoring, and dealing with various matters concerning special interest activities (e.g., swimming, caving, or climbing skills, and giving first aid in case of an accident).

Furthermore, Pattunuang NTO facilities such as roads, shelter, and bathrooms were limited and failed to function optimally. The basic infrastructure needs to be improved such as equipment of river tubing, rock climbing, camping, first aid, and separate bathrooms and toilets for male and female, garbage, lighting along the trail, signage, announcement boards, as well as the arrangement of campsites, location of a campfire, and parking lots. The 
Putri I. A.S.L.P., Ansari F.: Managing Nature-Based Tourism in Protected Karst Area Based on Tourism Carrying Capacity Analysis

manager also needs to add other new infrastructure capable of increase the attractiveness of Pattunuang NTO and ensure visitors are willing to undergo adventures.

According to Marsiglio (2015), the optimal number of visitors is smaller than the value of tourism carrying capacity. Therefore, an increasing number of visitors cannot exceed the carrying capacity value. The Pattunuang NTO carrying capacity value is multi-dimensional reviewed. Therefore, efforts to manage Pattunuang NTO by its carrying capacity value should be wisely chosen, by considering the local conditions of destination, for example, the level of sensitivity to disturbances or the level of uniqueness.

Pattunuang NTO is located in the karst ecosystem of a conservation area. Karst ecosystem are unique and sensitive to disruption and damages (Gutiérrez et al., 2014). Consequently, the manager needs to consider natural resources' ability to recover after disturbed by visitors' activities. The smallest visitor number on ecological carrying capacity will minimize visitor' pressure and providing more opportunity for nature to recover.

The social, physical, and real carrying capacity values of the Pattunuang NTO are higher than ecological and effective carrying capacity. Determination of the highest limit of the carrying capacity on the number of visitors impressed more profitable and cause the income from the entrance ticket increase drastically. However, the management of Pattunuang NTO should consider the effective carrying capacity value which is still relatively low due to the low value of the management capacity. There fore the management of Pattunuang NTO needs to increase their management capacity first, before allowing to increase the visitor numbers base on social, or physical, or real carrying capacity values. Consequently, currently, efforts to increase the number of visitors should only be carried out before it reaches the limit value of the ecological and effective carrying capacity.

\section{ACKNOWLEDGMENT}

We thank the Environment and Forestry Research and Development Institute of Makassar (Balai Penelitian dan Pengembangan Lingkungan Hidup dan Kehutanan Makassar), and Bantimurung Bulusaraung National Park for supporting this research.

\section{Funding acknowledgment statement}

The Environment and Forestry Research and Development Institute of Makassar, Annual grant 2015.

\section{CONFLICTS OF INTEREST}

The authors declare no conflict of interest.

\section{REFERENCES}

Al-Ghamdi, A., Adgaba, N., Getachew, A., \& Tadesse, Y. (2016). New approach for determination of an optimum honeybee colony's carrying capacity based on productivity and nectar secretion potential of bee forage species. Saudi Journal of Biological Sciences, 23(1), 92-100. doi:10.1016/j.sjbs.2014.09.020 
Bera, S., Das Majumdar, D., \& Paul, A. (2015). Estimation of Tourism Carrying Capacity for Neil Island, South Andaman, India. Jurnal of Coastal Sciences, 2(2-2015), 46-53. doi:10.6084/M9.FIGSHARE.1533035

Butler, R. W. (2017). Issues in applying carrying capacity concepts: examples from the United Kingdom. In H. Coccossis \& A. Mexa (Eds.), New Directions in Tourism Analysis: The Challenge of Tourism Carrying Capacity Assessment: Theory and Practice. London: Routledge.

Calanog, L. A. (2015). A Manual on Computing Carrying Capacity of Ecotourism Sites in Protected Area. Laguna: Ecosystem Research and Development Bureau Department of Environment and Natural Resources College. Philippine: Department of Environment and Natural Resources-Ecosystems Research and Development Bureau.

Chapman, E. J., \& Byron, C. J. (2018). The flexible application of carrying capacity in ecology. Global Ecology and Conservation, 13, e00365. doi:10.1016/j.gecco.2017.e00365

Clancy, S. A., Worrall, F., Davies, R. J., \& Gluyas, J. G. (2018). An assessment of the footprint and carrying capacity of oil and gas well sites: The implications for limiting hydrocarbon reserves. Sci Total Environ, 618, 586-594. doi:10.1016/j.scitotenv.2017.02.160

Coccossis, H. (2017). Chapter 1. Sustainable Tourism and Carrying Capacity: A New Context. Part I. Methodological Issues in Respect to Defining, Measuring and Evaluating Tourism Carrying Capacity. In H. Coccossis \& A. Mexa (Eds.), New Directions in Tourism Analysis: The Challenge of Tourism Carrying Capacity Assessment: Theory and Practice. London: Routledge.

Coccossis, H., \& Mexa, A. (2017). Introduction. In H. Coccossis \& A. Mexa (Eds.), New Directions in Tourism Analysis: The Challenge of Tourism Carrying Capacity Assessment: Theory and Practice. London: Routledge.

David, G. S., Carvalho, E. D., Lemos, D., Silveira, A. N., \& Dall'Aglio-Sobrinho, M. (2015). Ecological carrying capacity for intensive tilapia ( Oreochromis niloticus ) cage aquaculture in a large hydroelectrical reservoir in Southeastern Brazil. Aquacultural Engineering, 66, 30-40. doi:10.1016/j.aquaeng.2015.02.003

De Sousa, R. C., Pereira, L. C. C., Da Costa, R. M., \& Jiménez, J. A. (2014). Tourism carrying capacity on estuarine beaches in the Brazilian Amazon region. Journal of Coastal Research, 70, 545-550. doi:10.2112/si70-092.1

Douglass, R. W. (1975). Forest recreation 2nd ed. New York: Pergamon Press Inc.

DPJLHK. (2015). Rencana Strategis Direktorat Pemanfaatan Jasa Lingkungan Hutan Konservasi 2015-2019. Bogor, Indonesia: Kementerian Lingkungan Hidup dan Kehutanan.

Engineers, U. A. C. (1983). Hickory Spring Creeks Flood Control Plan Permit: Environmental Impact Statement Vol 1. Illinois: Will County.

Etikan, I. (2016). Comparison of Convenience Sampling and Purposive Sampling. American Journal of Theoretical and Applied Statistics, 5(1). doi:10.11648/j.ajtas.20160501.11

Fachrul, M. F. (2012). Metode Sampling Bioekologi (First ed. Vol. 1). Jakarta, Indonesia: Bumi Aksara.

Fandeli, C. (2002). Perencanaan Kepariwisataan Alam. Yogyakarta: Fakultas Kehutanan Universitas Gadjah Mada.

Graefe, A. R. (1988). Social psychological carrying capacity. Paper presented the Outdoor Recreation Benchmark 1988: Proceedings of the National Outdoor Recreation Forum, Tampa, Florida. 
Putri I. A.S.L.P., Ansari F.: Managing Nature-Based Tourism in Protected Karst Area Based on Tourism Carrying Capacity Analysis

Gutiérrez, F., Parise, M., De Waele, J., \& Jourde, H. (2014). A review on natural and human-induced geohazards and impacts in karst. Earth-Science Reviews, 138, 61-88. doi:10.1016/j.earscirev.2014.08.002

Hagy, H. M., \& Kaminski, R. M. (2015). Determination of foraging thresholds and effects of application on energetic carrying capacity for waterfowl. PLoS One, 10(3), e0118349. doi:10.1371/journal.pone.0118349

Hallo, J. C., \& Manning, R. E. (2010). Analysis of the Social Carrying Capacity of a National Park Scenic Road. International Journal of Sustainable Transportation, 4(2), 75-94. doi:10.1080/15568310802438940

Hammitt, W. E., Cole, D. N., \& Monz, C. A. (2015). Wildland Recreation: Ecology and Management. West Sussex, United Kingdom: John Wiley \& Sons, Ltd.

Han, Y., Wei, F., Ye, G., Yang, S., Ma, P., \& Hu, W. (2018). A study on evaluation the marine carrying capacity in Guangxi Province, China. Marine Policy, 91, 66-74. doi:10.1016/j.marpol.2018.02.003

Hasan, S. R., Hassan, K., \& Islam, M. S. (2014). Tourist-group consideration in tourism carrying capacity assessment: a new approach for the Saint Martin's Island Bangladesh. Journal of Economics and Sustainable Development, 5 (19), 150-158.

Indonesian Central Bureau of Statistics. (2017). Kabupaten Maros dalam angka 2017 (Maros Regency in number 2017).

Inkson, C., \& Minnaert, L. (2018). Tourism Management: An Introduction Second Edition. London: SAGE Publications Ltd.

Kruger, M., \& Saayman, M. (2014). The determinants of visitor length of stay at the Kruger National Park. Koedoe, 56(2). doi:10.4102/koedoe.v56i2.1114

Manning, R. E., Anderson, L. E., \& Pettengill, P. R. (2017). Managing outdoor recreation: Case studies in the national parks. London, United Kingdom: CABI.

Marsiglio, S. (2015). On the carrying capacity and the optimal number of visitors in tourism destinations. Tourism Economics, 23(3), 632-646. doi:10.5367/te.2015.0535

Martire, S., Castellani, V., \& Sala, S. (2015). Carrying capacity assessment of forest resources: Enhancing environmental sustainability in energy production at local scale. Resources, Conservation and Recycling, 94, 11-20. doi:10.1016/j.resconrec.2014.11.002

Mashayekhan, A., Calichi, M. M., Rassam, G. H., Hoseini, V., Jalilvand, H., Moslemi, S. M., \& Mohalleh, S. (2014). Recreation Carrying Capacity Estimations to Support Forest Park Management (Case Study: Telar Forest Park, Ghaemshahr, Iran). World Applied Sciences Journal. doi:10.5829/idosi.wasj.2014.29.03.1571

Mason, P. (2015). Tourism Impact, Planning and Management. London: Routledge.

Massiani, J. (2012). The relevance of the concept of capacity for the management of a tourist destination: theory and application to tourism management in Venice. RIEDS - Rivista Italiana di Economia, Demografia e Statistica - Italian Review of Economics, Demography and Statistics, 66(2), 141-156.

McCool, S. F., Clark, R. N., \& Stankey, G. H. (2007 ). An assessment of frameworks useful for public land recreation planning (Vol. No.PNW-GTR-705). Portland, U.S: Department of Agriculture, Forest Service, Pacific Northwest Research Station.

Moscardo, G. (2017). Guidelines for Managing Mainland Chinese Tourists to National Parks. Australia: Jamescook University. 
Papayannis, T. (2017). Tourism carrying capacity in areas of ecological importance. In H. Coccossis \& A. Mexa (Eds.), New Directions in Tourism Analysis: The Challenge of Tourism Carrying Capacity Assessment: Theory and Practice (pp. 312). London: Routledge.

Presiden Republik Indonesia. (2009). Undang Undang No. 32 Tahun 2009 Tentang: Perlindungan dan Pengelolaan Lingkungan Hidup (Law No.32 of 2009 about Protection and Environmental Management).

Putri, I. A., Ansari, F., \& Susilo, A. (2019). Response of bird community toward tourism activities in the karst area of Bantimurung Bulusaraung National Park. Journal of Quality Assurance in Hospitality \& Tourism. doi:10.1080/1528008X.2019.1631725

Queiroz, R. E., Ventura, M. A., Guerreiro, J. A., \& Cunha, R. T. d. (2014). Carrying capacity of hiking trails in Natura 2000 sites: a case study from North Atlantic Islands (Azores, Portugal). Revista de Gestão Costeira Integrada, 14(2), 233-242. doi:10.5894/rgci471

Rahmani, A., Fakhraee, A., Karami, S., \& Kamari, Z. (2015). A Quantitative Approach to Estimating Carrying Capacity in Determining the Ecological Capability of Urban Tourism Areas (Case Study: Eram Boulevard of Hamadan city). Asia Pacific Journal of Tourism Research, 20(7), 807-821. doi:10.1080/10941665.2014.934702

Reid, S. E., \& Marion, J. L. (2005). A comparison of campfire impacts and policies in seven protected areas. Environ Manage, 36(1), 48-58. doi:10.1007/s00267-003-0215-y

Ren, C., Guo, P., Li, M., \& Li, R. (2016). An innovative method for water resources carrying capacity research--Metabolic theory of regional water resources. J Environ Manage, 167, 139-146. doi:10.1016/j.jenvman.2015.11.033

Salerno, F., Viviano, G., Manfredi, E. C., Caroli, P., Thakuri, S., \& Tartari, G. (2013). Multiple Carrying Capacities from a management-oriented perspective to operationalize sustainable tourism in protected areas. $J$ Environ Manage, 128, 116-125. doi:10.1016/j.jenvman.2013.04.043

Sarker, S., \& Wiltshire, K. H. (2017). Phytoplankton carrying capacity: Is this a viable concept for coastal seas? Ocean \& Coastal Management, 148, 1-8. doi:10.1016/j.ocecoaman.2017.07.015

Sayan, M. S., \& Atik, M. (2011). Recreation Carrying Capacity Estimates for Protected Areas: A Study of Termessos National Park. Ekoloji, 20(78), 66-74. doi:10.5053/ekoloji.2011.7811

Sievänen, T. (2004). Recreation: Inventory, monitoring and management. Encyclopedia of forest sciences/Ed. Burley, J., Evans, J. \& Youngquist, JA.

Tejada, J. J., \& Punzalan, J. R. B. (2012). On the Misuse of Slovin's Formula. The Philippine Statistician Vol., 61. No.1, 129-136.

Thapa, K., \& Kelly, M. J. (2017). Density and carrying capacity in the forgotten tigerland: Tigers in the understudied Nepalese Churia. Integr Zool, 12(3), 211-227. doi:10.1111/1749-4877.12240

Vujko, A., Plavša, J., Petrović, M., Radovanovic, M., \& Gajić, T. (2017). Modelling of carrying capacity in National Park - Fruška Gora (Serbia) case study (Vol. 2017).

Watson, J., Smith, E. H., Gillieson, D., \& Kiernan, K. (1997). Guidelines for cave and karst protection (J. Watson, E. H. Smith, D. Gillieson, \& K. Kiernan Eds.). Cambridge, United Kingdom: IUCN, Gland, Switzerland, and Cambridge.

Yahya, A. (2017). Pariwisata Sebagai Core Ekonomi Negara. Retrieved from http://www.kemenpar.go.id/asp/detil.asp?c=193\&id=3443 
Putri I. A.S.L.P., Ansari F.: Managing Nature-Based Tourism in Protected Karst Area Based on Tourism Carrying Capacity Analysis

Zacarias, D. A., Williams, A. T., \& Newton, A. (2011). Recreation carrying capacity estimations to support beach management at Praia de Faro, Portugal. Applied Geography, 31(3), 1075-1081. doi:10.1016/j.apgeog.2011.01.020

Zelenka, J., \& Kacetl, J. (2014). The concept of carrying capacity in tourism. Amfiteatru Economic Journal, XVI(36), 641-654 (En), 501 (Ro).

Zhou, Y., \& Zhou, J. (2017). Urban atmospheric environmental capacity and atmospheric environmental carrying capacity constrained by GDP-PM 2.5. Ecological Indicators, 73, 637-652. doi:10.1016/j.ecolind.2016.10.015 